\title{
PEMBUATAN MINUMAN EMPON-EMPON DAN WEDANG ALANG-ALANG BAGI IBU-IBU DESA MARENGAN LAOK, KECAMATAN KALIANGET, KABUPATEN SUMENEP
}

\author{
Oleh: \\ Tukiran $^{1}$, Suyatno ${ }^{2}$, Nurul Hidajati ${ }^{3}$, Leny Yuanita ${ }^{4}$ \\ 1,2,3,4 Jurusan Kimia FMIPA Unesa Surabaya \\ ${ }^{1}$ tukiran@unesa.ac.id
}

\begin{abstract}
Abstrak
Diinformasikan bahwa Ibu-ibu warga Desa Marengan Laok, Kec. Kalianget, Sumenep belum berpengalaman dalam membuat minuman kesehatan berbasis herbal dalam bentuk cair dan juga bentuk serbuk (instan). Sementara itu, bahan untuk membuatnya banyak ditanam di sekitar rumah warga atau dengan mudah dapat dibeli di pasar terdekat. Banyaknya warung-warung makanan, toko, dan tempat penginapan yang berada di wilayah Desa Marengan Laok, Kec. Kalianget Sumenep ditambah lagi Sumenep sebagai kota wisata sangat mendukung penjualan produk minuman kesehatan berbasis herbal tersebut. Oleh karena itu, tujuan dari kegiatan PKM ini adalah memberikan kegiatan pelatihan kepada ibu-ibu rumah tangga warga desa tersebut untuk meningkatkan keterampilannya dalam pembuatan minuman kesehatan berbasis herbal yang hasilnya dapat berpotensi untuk meningkatkan pendapatan ekonomi keluarga. Pelatihan pembuatan berbagai minuman kesehatan berbasis herbal berbentuk cair, yaitu sirup empon-empon dan wedang alang-alang dan dan serbuk, yaitu minuman jahe instan yang siap dijual di warung dan toko jamu. Kegiatan PKM ini telah dilaksanakan pada bulan Agustus 2019 dengan melibatkan 9 orang ibu rumah tangga desa Marengan Laok dengan diawali pemaparan materi pelatihan oleh Tim PKM, dilanjutkan dengan pendampingan praktek pembuatan minuman kesehatan berbasis herbal, dan diakhiri dengan refleksi/umpan balik serta pemberian angket. Target kegiatan PKM ini adalah meningkatnya keterampilan ibu-ibu rumah tangga desa Marengan Laok dalam pembuatan minuman kesehatan berbasis herbal. Adapun hasil angket dapat diketahui bahwa kegiatan PKM dinyatakan telah berjalan dengan baik dan lancar serta peserta mampu memahami dan terampil dalam membuat minuman kesehatan berbasis herbal tersebut. Saran dari peserta antara lain lama waktu pelatihan hendaknya ditambah, frekuensi pelatihan hendaknya sesering mungkin, dan ragam minuman kesehatan berbasis herbal ditambah lagi.
\end{abstract}

Kata Kunci: Pelatihan, minuman herbal, sirup empon-empon, Sumenep, wedang alang-alang

\begin{abstract}
It was informed that the women who were residents of Marengan Laok Village, Kalianget, Sumenep has no experience in making herbal-based health drinks in liquid and in powder (instant) forms. Meanwhile, the ingredients for making it are widely planted around people's homes or can easily be purchased at the nearest market. The number of food stalls, shops, and lodging places in the village area, Kalianget Sumenep and also Sumenep as a tourist city strongly supports the sale of herbal-based health drink products. Therefore, the purpose of this PKM activity is to provide training activities to housewives from the village to improve their skills in making herbal-based health drinks, the results of which have the potential to increase family economic income. Training on making various herbal-based health drinks in liquid form, namely empon-empon syrup and wedang alang-alang and in powder form, namely instant ginger drinks that are ready to be sold in stalls and herbal shops. This PKM activity was carried out in August 2019 by involving 9 housewives in Marengan Laok village, starting with the presentation of training materials by the PKM Team, followed by mentoring in the practice of making herbal-based health drinks, and ending with reflection/feedback and giving a questionnaire. The target of this PKM activity is to increase the skills of housewives in Marengan Laok village in making herbal-based health drinks. As for the results of the questionnaire, it can be seen that the PKM activities were declared to have run well and smoothly and the participants were able to understand and be skilled in making these herbal-based health drinks. Suggestions from the participants included increasing the length of the training time, the frequency of training should be as often as possible, and the variety of herbal-based health drinks should be added.
\end{abstract}

Keywords: Training, herbal drinks, empon-empon syrup, Sumenep, wedang alang-alang

\section{PENDAHULUAN}

Desa Marengan Laok merupakan salah satu desa di kecamatan Kalianget, kabupaten Sumenep dimana sebagian warga desanya bekerja sebagai petani garam, buruh tani garam, tukang kayu, tukang batu, kuli bangunan, penjual sayur keliling, membuka warung makanan dan mrancang. Sementara itu sebagian besar ibu rumah tangganya bekerja sebagai pembantu rumah tangga, buruh cuci dan seterika, serta berjualan aneka kebutuhan sehari-hari di rumah (mrancang). Dengan demikian, sebagian besar warga memiliki penghasilan yang pas-pasan untuk memenuhi kebutuhan hidup. Upaya pelatihan guna meningkatkan keterampilan warga desa Marengan Laok sangat diperlukan untuk meningkatkan pendapatan ekonomi keluarganya.

Berdasarkan hasil wawancara kami dengan ibu rumah tangga warga Desa Marengan Laok, 
Kec. Kalianget, Sumenep diperoleh informasi bahwa mereka belum berpengalaman dalam membuat minuman kesehatan berbasis herbal dalam bentuk cair dan serbuk (instant), khususnya minuman empon-empon (Anonim, 2018a; 2021a; Wijaya, 2021a; 2021b), wedang alang-alang (Anonim, 2018b), dan minuman jahe instan (Anonim, 2021b). Banyak sumber penelitian dan kajian terkait manfaat tumbuhan herbal sebagai tumbuhan obat yang telah dikompilasi ke dalam sebuah buku yang dapat digunakan sebagai pedoman atau acuan dalam menyiapkan minuman kesehatan berbasis herbal (Mallaleng, dkk., 2011 dan 2012). Sementara itu bahan untuk membuatnya banyak ditanam di sekitar rumah warga atau dengan mudah dapat diperoleh di pasar terdekat. Banyaknya warung-warung makanan, toko, dan tempat penginapan yang berada di wilayah Desa Marengan Laok, Kec. Kalianget Sumenep ditambah lagi Sumenep sebagai kota wisata sangat mendukung penjualan produk minuman kesehatan berbasis herbal tersebut. Oleh karena itu, dalam rangka membantu pemerintah, khususnya Pemkab Sumenep maka kami bermaksud menawarkan dan memberikan kegiatan pelatihan kepada ibu-ibu rumah tangga warga Desa Marengan Laok, Kec. Kalianget, Sumenep untuk meningkatkan keterampilannya dalam pembuatan minuman kesehatan berbasis herbal yang hasilnya dapat berpotensi untuk meningkatkan pendapatan ekonomi keluarga. Kegiatan serupa pernah dilakukan di desa Kandangan, kecamatan Kandangan, Kabupaten Kediri (Tukiran, dkk., 2019). Kegiatan PKM ini diharapkan dapat mencapai target sebagai berikut: 1) Meningkatkan keterampilan ibu rumah tangga warga Desa Marengan Laok, Kec. Kalianget, Sumenep dalam membuat minuman kesehatan berbasis herbal. Di akhir kegiatan pelatihan ini diharapkan minimal $80 \%$ peserta pelatihan memiliki keterampilan pembuatan minuman kesehatan berbasis herbal dengan kategori minimal baik dan 2) Mendapatkan respon positif dari para ibu rumah tangga warga desa Marengan Laok, Kec. Kalianget, Sumenep terhadap kegiatan pelatihan pembuatan minuman kesehatan berbasis herbal dengan kategori minimal baik.

\section{METODE PELAKSANAAN}

Tahapan pelatihan pembuatan minuman kesehatan berbasis herbal untuk membekali keterampilan para ibu rumah tangga di Desa Marengan Laok adalah sebagai berikut:

1. Membuat atau menyiapkan materi pembuatan minuman kesehatan berbasis herbal dengan mengacu pada sumber bacaan berikut: Sukmawati, W. dan Merina, 2019; Susanty, S. dan Yulendra, L., 2018; Suyatno, dkk., 2020; Wijaya, 2021a; 2021b.

2. Pemaparan materi pembuatan minuman kesehatan berbasis herbal berbentuk cair.

3. Memberikan contoh pembuatan minuman kesehatan berbasis herbal dengan melibatkan peserta pelatihan menggunakan bahan-bahan yang telah disediakan.

4. Praktek mandiri pembuatan minuman kesehatan berbasis herbal yang dilakukan oleh ibu rumah tangga peserta pelatihan. Pada tahap ini peserta pelatihan dibagi menjadi 2 kelompok (tiap kelompok beranggotakan 4-5 orang) dan masing-masing kelompok melakukan praktek pembuatan sirup empon-empon, wedang alang-alang dan minuman jahe instan. Keterampilan peserta di tiap kelompok diukur menggunakan lembar penilaian kinerja.

5. Melakukan refleksi/umpan balik dan masukan/opini/pendapat dan saran para peserta pelatihan tentang hasil pelatihan yang telah dilaksanakan.

6. Melakukan monitoring dan evaluasi terhadap pelaksanaan pelatihan dan diikuti pemberian lembar angket untuk mengetahui respon peserta pelatihan terhadap kegiatan pelatihan yang telah dilakukan.

\section{HASIL DAN PEMBAHASAN}

Kegiatan PKM ini disepakati bersama dan dilaksanakan di Balai Kelurahan Desa Marengan Laok, Kabupaten Kalianget, Sumenep pada tanggal 19-20 Juli 2019 mulai pagi jam 08.00 sd 13.00 dengan diikuti 9 peserta dengan usia berkisar antara 25-35 tahun. Berikut adalah nama-nama peserta yang ikut kegiatan PKM "Pembuatan Minuman Kesehatan Berbasis Herbal Berbentuk Cair dan Serbuk (Instan)", seperti terlihat pada Tabel 1.

Tabel 1. Peserta pada Kegiatan PKM "Pembuatan Minuman Kesehatan Berbasis Herbal Berbentuk Cair dan Serbuk (Instan)"

\begin{tabular}{|l|l|l|l|l|l|}
\hline No & Nama & $\begin{array}{l}\text { Jenis } \\
\text { Kelamin }\end{array}$ & No & Nama & $\begin{array}{l}\text { Jenis } \\
\text { Kelamin }\end{array}$ \\
\hline 1 & $\mathrm{IY}$ & $\mathrm{P}$ & 6 & Sis & $\mathrm{P}$ \\
\hline 2 & $\mathrm{Mn}$ & $\mathrm{P}$ & 7 & Dam & $\mathrm{P}$ \\
\hline 3 & $\mathrm{Sad}$ & $\mathrm{P}$ & 8 & Las & $\mathrm{P}$ \\
\hline 4 & $\mathrm{Ti}$ & $\mathrm{P}$ & 9 & Har & $\mathrm{P}$ \\
\hline 5 & Sum & $\mathrm{P}$ & & & \\
\hline
\end{tabular}


Berikut adalah foto-foto kegiatan PKM yang dimulai dari:

1. Sambutan oleh Kepala Desa Marengan Laok, Kabupaten Kalianget, Sumenep dan Pimpinan Jurusan Kimia, FMIPA, Unesa

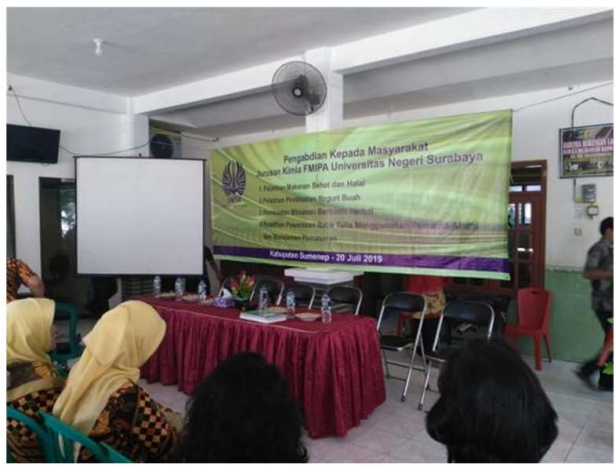

Para tim pelaksana PKM dan khalayak masyarakat siap mengikuti acara Pembukaan

2. Pemberian Materi PKM oleh Ketua Pelaksana PKM dan Praktek Membuat Minuman Kesehatan Berbasis Herbal oleh Peserta Didampingi TIM Pelaksana PKM.

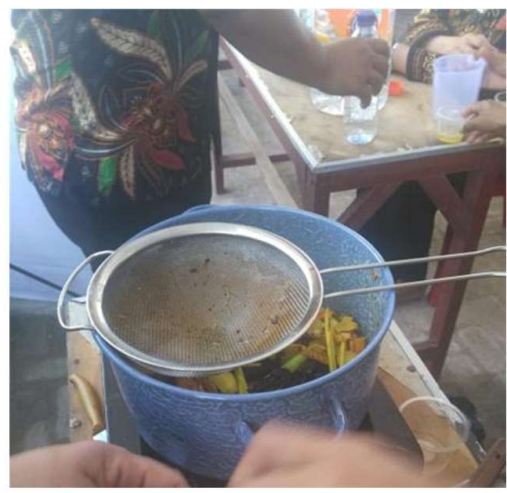

Mitra telah selesai membuat sirup empon-empon

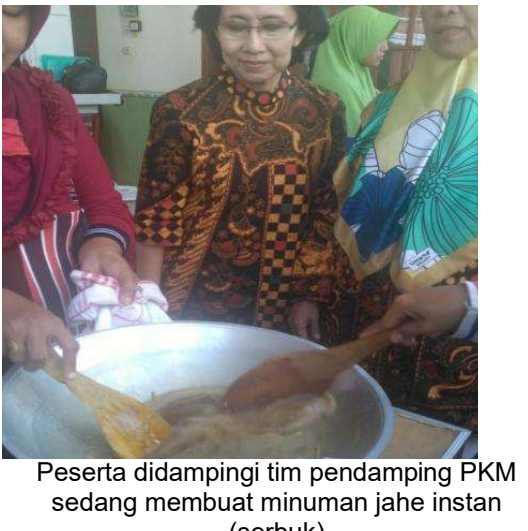
(serbuk)

\section{A. Analisis data hasil PKM}

Untuk mengetahui sejauhmana pemberdayaan masyarakat desa Marengan Laok (mitra) dalam

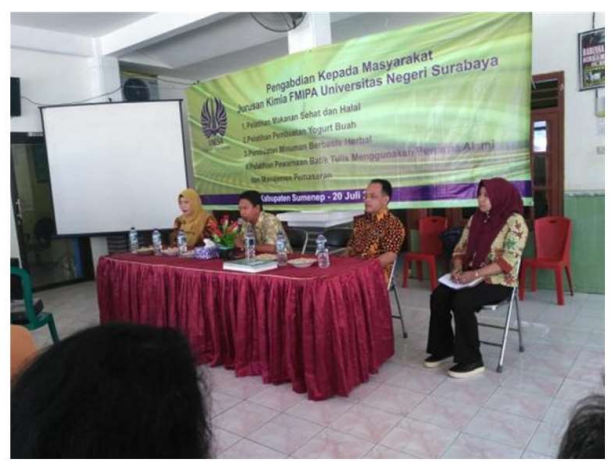

Sekretaris Desa Memberi Sambutan dan Sekaligus Membuka Resmi Acara PKM

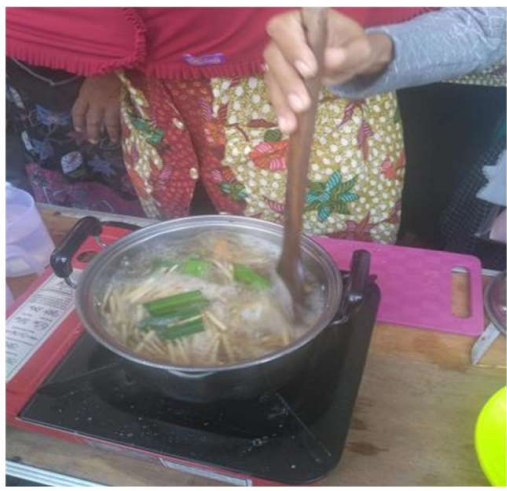

Para peserta praktek membuat wedang alangalang

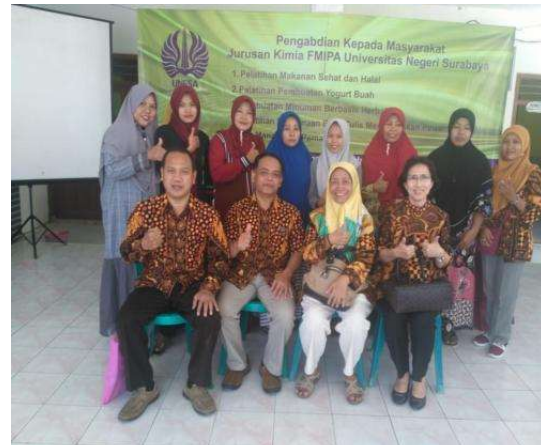

Peserta bersama tim pendamping PKM berfoto bersama setelah acara selesai

memenuhi target capaiannya, yaitu mereka memiliki keterampilan pembuatan minuman kesehatan berbasis herbal berbentuk cair 
mencakup sirup empon-empon (Tabel 2) dan wedang alang-alang (Tabel 3) dilakukanlah penilaian oleh 4 panelis terhadap kinerja mereka dan hasilnya dapat ditunjukkan pada Tabel 2 dan Tabel 3. Sementara, penilaian keterampilan terhadap pembuatan minuman kesehatan berbentuk serbuk jahe instan tidak dilakukan disebabkan waktu tidak mencukupi.

Tabel 2 Penilaian Keterampilan Pembuatan Sirup Empon-empon

\begin{tabular}{|c|c|c|c|c|c|c|c|c|c|c|c|c|c|c|c|c|c|}
\hline \multirow{3}{*}{ No } & \multirow{3}{*}{ Rincian Tugas Kinerja } & \multicolumn{16}{|c|}{ Skor } \\
\hline & & \multicolumn{4}{|c|}{$\mathbf{A}$} & \multicolumn{4}{|c|}{ B } & \multicolumn{4}{|c|}{ C } & \multicolumn{4}{|c|}{ D } \\
\hline & & 1 & 2 & 3 & 4 & 1 & 2 & 3 & 4 & 1 & 2 & 3 & 4 & 1 & 2 & 3 & 4 \\
\hline 1 & $\begin{array}{l}\text { Mencuci rimpang temulawak, } \\
\text { kunyit, dan jahe }\end{array}$ & & & $X$ & & & & & $X$ & & & & $x$ & & & & $X$ \\
\hline 2 & $\begin{array}{l}\text { Mengiris tipis-tipis rimpang } \\
\text { temulawak, kunyit, dan jahe yang } \\
\text { telah dicuci }\end{array}$ & & & & $\mathrm{X}$ & & & $x$ & & & & & $\mathrm{X}$ & & & & $\mathrm{X}$ \\
\hline 3 & $\begin{array}{l}\text { Memasukkan irisan temulawak, } \\
\text { kunyit, dan jahe ke dalam panci } \\
\text { yang berisi air yang telah } \\
\text { dipanaskan }\end{array}$ & & & & $\mathrm{X}$ & & & & $\mathrm{X}$ & & & & $\mathrm{X}$ & & & & $\mathrm{X}$ \\
\hline 4 & $\begin{array}{l}\text { Memasukkan asam, sereh, bunga } \\
\text { rosella, dan gula pasir }\end{array}$ & & & & $X$ & & & & $X$ & & & & $x$ & & & & $X$ \\
\hline 5 & \begin{tabular}{|l|} 
Memanaskan dan mengaduk \\
campuran hingga semua gula larut \\
\end{tabular} & & & & $X$ & & & $\mathrm{X}$ & & & & & $X$ & & & & $X$ \\
\hline 6 & Menyajikan sirup empon-empon & & & & $\mathrm{X}$ & & & & $\mathrm{X}$ & & & & $\mathrm{X}$ & & & & $\mathrm{X}$ \\
\hline $\begin{array}{l}\text { Ketel } \\
\text { Penil } \\
1=\end{array}$ & $\begin{array}{l}\text { npak pada Tabel } 2 \text { bahwa semua } \\
\text { akat bahwa peserta sudah dapat dik } \\
\text { niliki keterampilan dalam me } \\
\text { uman/wedang empon-empon khu } \\
\text { memasukkan irisan temulawak, } \\
\text { jahe ke dalam panci yang berisi a } \\
\text { h dipanaskan; memasukkan asam, }\end{array}$ & hulis & dan & & & \multicolumn{12}{|c|}{$\begin{array}{l}\text { bunga rosella, dan gula pasir ke dalam panci; } \\
\text { dan menyajikan sirup empon-empon dengan } \\
\text { kriteria sangat baik. Sementara, keterampilan } \\
\text { dalam mencuci rimpang temulawak, kunyit, dan } \\
\text { jahe; mengiris tipis-tipis rimpang temulawak, } \\
\text { kunyit, dan jahe yang telah dicuci; dan } \\
\text { memanaskan dan mengaduk campuran hingga } \\
\text { semua gula larut dua panelis menyatakan dalam } \\
\text { kategori baik dan sangat baik. Karena, minimal } \\
80 \% \text { peserta pelatihan memiliki keterampilan } \\
\text { pembuatan minuman kesehatan berbasis herbal } \\
\text { dengan kategori minimal baik, maka target } \\
\text { pelatihan kegiatan ini telah terpenuhi }\end{array}$} \\
\hline
\end{tabular}

Tabel 3. Penilaian Keterampilan Pembuatan Wedang Alang-alang

\begin{tabular}{|c|c|c|c|c|c|c|c|c|c|c|c|c|c|c|c|c|c|}
\hline \multirow{3}{*}{ No } & \multirow{3}{*}{ Rincian Tugas Kinerja } & \multicolumn{16}{|c|}{ Skor } \\
\hline & & \multicolumn{4}{|c|}{ A } & \multicolumn{4}{|c|}{ B } & \multicolumn{4}{|c|}{ C } & \multicolumn{4}{|c|}{ D } \\
\hline & & 1 & 2 & 3 & 4 & 1 & 2 & 3 & 4 & 1 & 2 & 3 & 4 & 1 & 2 & 3 & 4 \\
\hline 1 & $\begin{array}{l}\text { Mencuci alang-alang dan daun } \\
\text { pandan wangi hingga bersih }\end{array}$ & & & $X$ & & & & & $\mathrm{X}$ & & & & $X$ & & & & $\mathrm{X}$ \\
\hline 2 & $\begin{array}{l}\text { Membakar rimpang jahe dan } \\
\text { dimemarkan }\end{array}$ & & & & $\mathrm{X}$ & & & $\mathrm{X}$ & & & & $\mathrm{X}$ & & & & $\mathrm{X}$ & \\
\hline 3 & Mememarkan batang kamijoro & & & & $\mathrm{X}$ & & & & $\mathrm{X}$ & & & & $\mathrm{X}$ & & & & $\mathrm{X}$ \\
\hline 4 & $\begin{array}{l}\text { Mencampur semua bahan } \\
\text { tersebut menjadi satu, letakkan di } \\
\text { satu wadah }\end{array}$ & & & & $\mathrm{x}$ & & & $\mathrm{X}$ & & & & & $\mathrm{X}$ & & & & $\mathrm{X}$ \\
\hline 5 & $\begin{array}{l}\text { Merebus semua bahan tersebut } \\
\text { dalam air putih hingga mendidih } \\
\text { dan mulai mengeluarkan aroma } \\
\text { jahe }\end{array}$ & & & $\mathrm{X}$ & & & & & $\mathrm{X}$ & & & & $\mathrm{X}$ & & & & $\mathrm{X}$ \\
\hline 6 & $\begin{array}{l}\text { Mengaduk merata untuk } \\
\text { melarutkan gulanya, cicipi juga } \\
\text { sedikit demi sedikit jika kurang } \\
\text { manis tinggal tambahkan gula } \\
\text { hingga mendapatkan rasa yang } \\
\text { pas di lidah kamu }\end{array}$ & & & & $\mathrm{X}$ & & & & $\mathrm{X}$ & & & & $\mathrm{X}$ & & & & $\mathrm{X}$ \\
\hline 7 & $\begin{array}{l}\text { Wedang alang-alang tradisional } \\
\text { siap dinikmati }\end{array}$ & & & & $\mathrm{X}$ & & & & $\bar{X}$ & & & & $\mathrm{X}$ & & & & $\mathrm{X}$ \\
\hline
\end{tabular}


1 = Kurang baik, 2 = Cukup baik, 3 = Baik, dan $4=$ Sangat baik

Dari Tabel 3 nampak bahwa hampir semua peserta telah mampu dan terampil dalam membuat wedang alang-alang dengan kriteria sangat baik, kecuali mencuci alang-alang dan daun pandan wangi hingga bersih, membakar rimpang jahe dan dimemarkan, mencampur semua bahan tersebut menjadi satu, letakkan di satu wadah, dan merebus semua bahan tersebut dalam air putih hingga mendidih dan mulai mengeluarkan aroma jahe dengan kategori baik. Dengan demikian, secara keseluruhan peserta dinyatakan telah memiliki keterampilan membuat wedang alang-alang.
Tahap monitoring dan evaluasi dilakukan terhadap pelaksanaan PKM dan diikuti tanya jawab dan masukan/saran/komentar, serta diakhiri pemberian lembar angket terkait proses pelatihan dan pendampingan yang telah dilakukan. Adapun hasil analisis angket respon peserta terhadap pelaksanaan PKM di tempat mitra dapat dilaporkan sebagai berikut. Setelah kegiatan pelatihan dan pendampingan selesai dilakukan, peserta diberikan lembar angket respon terhadap pelaksanaan PKM. Hal ini bertujuan untuk melihat sejauhmana kegiatan tersebut dikatakan telah berjalan dengan baik serta telah mampu memberikan pemahaman dan penguatan akan keterampilan dalam membuat minuman kesehatan berbasis herbal bagi peserta. Hasil analisis data angket respon terhadap 9 peserta yang diperoleh dapat dilaporkan sebagaimana tercantum pada Tabel 4 berikut.

\section{B. Tahap Monitoring dan Evaluasi}

Tabel 4. Analisis Hasil Angket Respon Terhadap Pelaksanaan PKM Marengan Laok Sumenep

\begin{tabular}{|c|c|c|}
\hline No & Aspek & Keterangan \\
\hline 1 & $\begin{array}{l}\text { Mengapa Saudara mengikuti kegiatan pelatihan ini? } \\
\text { a. Diperintahkan oleh perangkat RT/ RW. } \\
\text { b. Mengikuti ajakan teman } \\
\text { c. Ingin memperoleh sumbangan } \\
\text { d. Ingin menambah pengetahuan dan keterampilan }\end{array}$ & $\begin{array}{l}\text { Semuanya }(100 \%) \text { menjawab: } \\
\text { d. Ingin menambah pengetahuan dan } \\
\text { keterampilan }\end{array}$ \\
\hline 2 & $\begin{array}{l}\text { Bagaimana sikap keluarga dengan keikutsertaan Saudara } \\
\text { pada kegiatan pelatihan ini? } \\
\text { a. Sangat mendukung } \\
\text { b. Mendukung } \\
\text { c. Kurang mendukung } \\
\text { d. Tidak mendukung }\end{array}$ & $\begin{array}{l}\text { Semuanya (100\%) menjawab: } \\
\text { a. Sangat mendukung }\end{array}$ \\
\hline 3 & $\begin{array}{l}\text { Menurut pendapat Saudara, bagaimana penyelenggaraan } \\
\text { kegiatan pelatihan ini? } \\
\text { a. Sangat baik } \\
\text { b. Baik } \\
\text { c. Kurang baik } \\
\text { d. Tidak baik }\end{array}$ & $\begin{array}{l}\text { Semuanya (100\%) menjawab: } \\
\text { a. sangat baik }\end{array}$ \\
\hline 4 & $\begin{array}{l}\text { Apakah kegiatan pelatihan ini menarik bagi Saudara? } \\
\text { a. Sangat menarik } \\
\text { b. Menarik } \\
\text { c. Kurang menarik } \\
\text { d. Tidak menarik }\end{array}$ & $\begin{array}{l}8 \text { orang menjawab: } \\
\text { a. sangat menarik }(88.9 \%) \text { dan sisanya } \\
1 \text { orang }(11,1 \%) \text { yang menjawab: b. } \\
\text { menarik. }\end{array}$ \\
\hline 5 & $\begin{array}{l}\text { Apakah kegiatan pelatihan ini bermanfaat bagi Saudara? } \\
\text { a. Sangat bermanfaat } \\
\text { b. Bermanfaat } \\
\text { c. Kurang bermanfaat } \\
\text { d. Tidak bermanfaat }\end{array}$ & $\begin{array}{l}8 \text { orang menjawab: } \\
\text { a. sangat bermanfaat }(88.9 \%) \text { dan } \\
\text { sisanya } 1 \text { orang }(11,1 \%) \text { menjawab: b. } \\
\text { bermanfaat. }\end{array}$ \\
\hline 6 & $\begin{array}{l}\text { Bagaimana pengetahuan dan keterampilan Saudara } \\
\text { setelah mengikuti kegiatan pelatihan ini? } \\
\text { a. Sangat meningkat } \\
\text { b. Meningkat } \\
\text { c. Kurang meningkat } \\
\text { d. Tidak ada perubahan }\end{array}$ & $\begin{array}{l}\text { Sebanyak } 5 \text { orang }(55,6 \%) \text { menjawab } \\
\text { meningkat dan sisanya } 4 \text { orang }(44,4 \%) \\
\text { menjawab meningkat. }\end{array}$ \\
\hline 7 & $\begin{array}{l}\text { Apakah Saudara yakin dapat melanjutkan hasil kegiatan } \\
\text { pelatihan ini di rumah? } \\
\text { a. Sangat yakin } \\
\text { b. Yakin } \\
\text { c. Kurang yakin } \\
\text { d. Tidak yakin }\end{array}$ & $\begin{array}{l}\text { Sebanyak } 6 \text { orang }(66,7 \%) \text { yang } \\
\text { menjawab a. sangat yakin dan } 3 \text { orang } \\
(33,3 \%) \text { menjawab b. yakin. }\end{array}$ \\
\hline 8 & Apakah sebelumnya Saudara pernah mengikuti kegiatan & 1. Sebanyak 5 orang $(55,6 \%)$ \\
\hline
\end{tabular}


Tukiran, dkk.., Pelatihan Pembuatan Minuman ...

\begin{tabular}{|c|c|c|}
\hline No & Aspek & Keterangan \\
\hline & $\begin{array}{l}\text { pelatihan semacam ini? } \\
\text { a. Sangat sering } \\
\text { b. Sering } \\
\text { c. Jarang } \\
\text { d. Tidak pernah }\end{array}$ & $\begin{array}{l}\text { menjawab d. tidak pernah. } \\
\text { 2. Ada } 3 \text { orang }(33,3 \%) \text { yang } \\
\text { menjawab b. sering. } \\
\text { 3. Ada } 1 \text { orang }(11,1 \%) \text { yang } \\
\text { menjawab c. jarang. }\end{array}$ \\
\hline 9 & $\begin{array}{l}\text { Bagaimana tanggapan anda terhadap materi yang } \\
\text { disampaikan narasumber? } \\
\text { a. Sangat mudah dipahami } \\
\text { b. Mudah dipahami } \\
\text { c. Cukup mudah dipahami } \\
\text { d. Sulit dipahami }\end{array}$ & $\begin{array}{l}\text { 1. Ada } 6 \text { orang }(66,7 \%) \text { menjawab a. } \\
\text { sangat mudah dipahami. } \\
\text { 2. Ada } 2 \text { orang }(22,1 \%) \text { menjawab b. } \\
\text { mudah dipahami. } \\
\text { 3. Ada } 1 \text { orang }(11,1 \%) \text { yang } \\
\text { menjawab c. cukup mudah } \\
\text { dipahami. }\end{array}$ \\
\hline 10 & $\begin{array}{l}\text { Manakah di antara kegiatan pelatihan hari ini yang } \\
\text { Saudara sukai? } \\
\text { a. Pembuatan minuman kesehatan Empon-empon } \\
\text { b. Pembuatan minuman kesehatan wedang alang-alang } \\
\text { c. Semua materi saya sukai } \\
\text { d. Semua materi tidak saya sukai }\end{array}$ & $\begin{array}{l}\text { 1. Ada } 8 \text { orang }(88,9 \%) \text { yang } \\
\text { menjawab c. semua materi saya } \\
\text { sukai } \\
\text { 2. Hanya } 1 \text { orang }(11,1 \%) \text { yang } \\
\text { menyukai bagian b. }\end{array}$ \\
\hline 11 & $\begin{array}{l}\text { Tuliskan saran Saudara berkaitan dengan kegiatan } \\
\text { pelatihan pada hari ini! }\end{array}$ & $\begin{array}{l}\text { Saran-saran dari } 9 \text { peserta adalah } \\
\text { sebagai berikut: } \\
\text { - } \quad \text { Waktunya lebih lama dan } \\
\text { ragamnya lebih banyak. } \\
\text { - } \quad \text { Pelatihan hari ini sangat } \\
\text { bermanfaat untuk sehari-hari yang } \\
\text { bisa dilakukan lagi di rumah. } \\
\text { - } \quad \text { Sangat bermanfaat dan menambah } \\
\text { pengetahuan dan keterampilan di } \\
\text { rumah. } \\
\text { - Semoga apa yang terlaksana hari } \\
\text { ini menjadi tambahan ilmu yang } \\
\text { berguna bagi kami. } \\
\text { Saya sarankan waktunya lebih } \\
\text { lama lagi. } \\
\text { Saran saya: sering-seringlah sudi } \\
\text { dating ke desa kami ini dan } \\
\text { mengadakan pelatihan kembali. } \\
\text { Terimakasih. } \\
\text { Kalau bisa sering mungkin } \\
\text { mengadakan pelatihan ini. } \\
\text { Kalau bisa diadakan } 1 \text { bulann } \\
\text { sekali pelatihan. } \\
\text { Kalau bisa sering-sering melakukan } \\
\text { pelatihan di desa kami. }\end{array}$ \\
\hline
\end{tabular}

\section{Bab 6. KESIMPULAN DAN SARAN}

\section{A. SIMPULAN}

Berdasarkan hasil kegiatan yang telah dilakukan dapat disimpulkan bahwa pelaksanaan pengabdian kepada masyarakat ini telah berjalan dengan baik dan lancar. Hal ini dapat diindikasikan dari keberhasilan peserta mampu membuat dengan terampil minuman kesehatan tersebut dengan baik dan lancar.

\section{B. SARAN}

Sebaiknya pihak mitra diberi kelonggaran waktu untuk kegiatan PKM tersebut, misal 3 kal selama pelatihan agar mampu menyerap ilmu tentang jenis/macam minuman kesehatan berbasis herbal dan kegunaannya serta mampu mengembangluaskan dengan baik di kemudian hari.
DAFTAR PUSTAKA

Anonim. (2018a). Minuman racikan empon - empon khas tradisional menyehatkan bagi tubuh. http://www.pastvnews.com/kuliner/minuma n-racikan-empon-empon-khas-tradisionalmenyehatkan-bagi-tubuh.html. Diakses pada tanggal 25 April 2018.

Anonim. (2018b). Wedang Alang-alang. https://id.tastemade.com/videos/wedangalang-alang. Diakses pada tanggal 25 April 2018.

Anonim. (2021a). Resep Minuman Empon-Empon Yang Lezat Sekali. https://Resepminumanterkini.Web.App/Mix /30-Resep-Minuman-Empon-Empon-YangLezat-Sekali/. Diakses pada tanggal 29 Juni 2021.

Anonim, (2021c). Bagaimana Membuat Wedang Jahe Instan Anti Gagal. https://sotosop.netlify.app/1402- 
bagaimana-membuat-wedang-jahe-instananti-gagal.html. Diakses pada tanggal 29 Juni 2021.

Mallaleng, H.R., Purwaningtyas, U., Hermawati, R., Solichah, N., dan Syah, F.Z.N. (2011). Tanaman Obat untuk Penyakit Sindrom Metabolisme. Malang: UM Press.

Mallaleng, H.R., Purwaningtyas, U., Hermawati, R., dan Solichah, N. (2012). Katalog Tumbuhan Obat Alam. Jilid 1. Batu: UPT Materia Medica Batu.

Sukmawati, W. dan Merina (2019). Pelatihan Pembuatan Minuman Herbal Instan Untuk Meningkatkan Ekonomi Warga, Jurnal Pengabdian kepada Masyarakat (PKM), 25(4), 210-215.

Susanty, S. dan Yulendra, L. (2018). Panduan Proses Pengolahan Jahe Menjadi Jahe Serbuk Instan, Media Bina IImiah, 1(1), 85 - 92.

Suyatno, Budi J., Endang S., Utiya A., dan Amiq F., (2020). Pelatihan Pembuatan Minuman Kesehatan Berbasis Herbal untuk Warga Desa Sirnoboyo, Kec. Benjeng, Kab, Gresik, Prosiding Seminar Nasional Kimia (SNK) 2020, Jurusan Kimia FMIPA Unesa 10 Oktober 2020, 304-313.

Tukiran, Suyatno, Nurul H., dan Samik. (2019). Pembuatan Minuman Kesehatan Berbasis Herbal Untuk Warga Desa Kandangan, Kecamatan Kandangan, Kabupaten Kediri, Jurnal ABDI, 5(1), 25-32.

Wijaya, Y.G. (2021a). Cara Membuat Dan Menyimpan Minuman Empon-Empon. https://Travel.Kompas.Com/Read/2020/03/ 20/230000927/Cara-Membuat-dan-

Menyimpan-Minuman-Empon-

Empon?Page=All. Diakses Pada Tanggal 29 Juni 2021.

Wijaya, Y.G. (2021b). Resep Membuat Wedang Alang-alang, Minuman yang Menghangatkan Tubuh, https://travel.kompas.com/read/2020/01/03 /101900427/resep-membuat-wedangalang-alang-minuman-yang-

menghangatkan-tubuh. Diakses Pada Tanggal 29 Juni 2021. 